\title{
Cranial transillumination in early and severe malnutrition
}

\author{
BY JAIME ROZOVSKI N., FERNANDO NOVOA S., \\ JORGE ABARZÚA F. AND FERNANDO MÖNCKEBERG B. \\ Pediatric Research Laboratory, Hospital Manuel Arriarán, University of Chile, \\ Casilla 5370, Santiago 3-Chile
}

(Received 23 March 1970-Accepted 20 Fuly 1970)

\begin{abstract}
I. By means of a cranial transillumination method used in conjunction with lumbar and bregmatic punctures, an increase in the space which contains the cerebro-spinal fluid in the cranial region is suggested in children with severe marasmic malnutrition.

2. The results appear to indicate that this is due to a diminished brain size, creating a space in the interior of the cranium which secondarily fills with cerebro-spinal fluid.
\end{abstract}

Studies in man as well as animals have shown that the effect of malnutrition on the central nervous system depends on the intensity, duration and time of life at which it occurs (Jackson \& Steward, I920; Widdowson, 1966; Winick \& Noble, 1966; Mönckeberg, 1967). There seems to be a critical period which corresponds to the time of maximum rate of brain growth, varying from one species to another (Scrimshaw, I 967). In man, this period of maximum brain growth occurs during the last few weeks before birth, gradually decreasing afterwards. At the moment of birth, brain weight is approximately $350 \mathrm{~g}$ and at 14 months of age is about $900 \mathrm{~g}$, at which time it has attained $80 \%$ its final weight (Stoch \& Smythe, 1967).

In experimental animals, malnutrition induced during this period of maximum brain growth produces, apart from histological alterations, a decrease in the growth rate (Jackson \& Steward, I920; Dobbing, I964; Dobbing \& Widdowson, 1965; Widdowson, Dickerson \& McCance, 1960). In the child who suffers severe malnutrition during the first few months of life, there is a decrease or even a cessation of physical growth which also affects the cranium (Mönckeberg, Donoso, Valiente \& Arteaga, 1967). If the malnutrition persists, it produces an atrophy of a number of tissues (Naeye, 1965 ), possibly including the brain. If this is so, it would result in a decreased brain volume, creating a space between itself and the rigid cranium. This space would naturally fill with some fluid, most likely cerebro-spinal fluid.

In this study we will try to prove the existence of that space by means of a cranial transillumination technique with simultaneous bregmatic puncture to determine the presence of cerebro-spinal fluid.

\section{EXPERIMENTAL}

Thirty-two infants with severe malnutrition were studied. These children were patients in our Metabolic Unit, Hospital Manuel Arriarán, University of Chile. Their ages ranged between 3 and $\mathrm{I} 2$ months, and all of them presented symptoms of marasmic-type malnutrition: muscular atrophy, lack of adipose tissue and apathy, but with absence of oedema or lesions of skin or mucosa, and with blood proteins and haematocrit within normal limits. In all of them, malnutrition was due to under- 
nutrition associated with poverty. Growth deficit in all instances was more than $50 \%$ the normal for their respective ages according to the Iowa standards (third degree marasmic malnutrition).

The control group was thirty infants, normal from a nutritional point of view, whose ages were also between 3 and 12 months.

The transillumination apparatus consists of a Multiblitz photographic flash model III B (Multiblitz-Gesellschaft für Multiblitzgeräte-Dr Ing. D. A. Mannesmann m.b.H.-505 Porz-Westhoven, Germany), which produces a light of $800 \mathrm{~W}$ for I s, the lamp diameter being $18 \mathrm{~cm}$. The flash is connected to a system for concentrating light, consisting of two plano-convex lenses, each $10 \mathrm{~cm}$ in diameter and having a focal distance of $8 \mathrm{~cm}$. The opening through which the beam of concentrated light is flashed has a diameter of $5 \mathrm{~cm}$; around the opening is attached a rubber ring allowing a close fit to the head of the child. The flash is connected to a camera which simultaneously photographs the area of transillumination and the head of the child (Pl. I a). The child's head is illuminated by two lamps of $200 \mathrm{~W}$ each. For each child a series of five transilluminations was made in the following positions: bregma, right parietal, left parietal, right frontal and left frontal (Pl. I $b$ ).

In both the malnourished and the control groups a superficial puncture was made in the external angle of the anterior fontanelle to obtain liquid. This liquid was analysed for total protein (Lowry, Rosebrough, Farr \& Randall, I95I), glucose (Somogyi, 1945) and bilirubin (Malloy \& Evelyn, 1937).

In eight children with severe malnutrition whose transilluminations showed an obvious space, liquid was obtained by both bregmatic and lumbar punctures. The following measurements were made on both samples: glucose, bilirubin, total protein, immunoelectrophoretic separation of proteins, and free amino acids. For the immunoelectrophoretic process, the proteins were concentrated by centrifugation of the fluid obtained in a tube whose lower end is formed by a nitrocellulose dialysis membrane.

Anti-serum to plasma proteins was prepared in a rabbit by injecting intramuscularly $28 \mathrm{mg}$ protein per kg body-weight twice a week for 4 weeks. The free amino acids were separated by bi-dimensional paper chromatography, using butanol-acetic acid and phenol-ammonia solvent (Smith, I958).

The distribution of ${ }^{131}$ I was studied in one infant aged 3 months, whose transillumination indicated a large space and from whom a large amount of liquid was obtained by bregmatic puncture. Two days before the injection and during the whole study, Lugol's iodine was administered in a dose of two drops every $12 \mathrm{~h}$. Human serum albumin labelled with ${ }^{131} \mathrm{I}$ was injected in the lumbar region into the subarachnoid space; the dose was $\mathrm{r} \cdot 48 \mu \mathrm{Ci} / \mathrm{kg}$. Samples of fluid were taken $2 \mathrm{~h}$ and $\mathrm{Ig} \mathrm{h}$ later by simultaneous bregmatic and lumbar puncture. At the same time, a blood sample was also taken. Radioactivity of all samples was recorded on a Baird Atomic 960 counter.

\section{RESULTS}

Transillumination. The difference between the transillumination of the normal children and those with malnutrition was striking, twenty-eight of the latter having a diameter of illumination greater than $10 \mathrm{~cm}$. In the majority of these, the diameter 
varied between $\mathrm{I} 2$ and $\mathrm{I} 5 \mathrm{~cm}$, but in some it was strikingly more intense, illuminating almost the entire cranium. Pl. $2 a$ illustrates typical case results. The positive transillumination of the children with malnutrition was homogeneous, the illumination appearing in all five positions and not confined to any particular region ( $\mathrm{Pl}$. I $b$ ).

As a general criterion, a transillumination was considered positive if it produced a halo of light more than $8 \mathrm{~cm}$ in diameter in all five positions. The measurement could be made objectively from the photographs for each patient. By this criterion, twentyeight of the thirty-two infants with severe malnutrition had a positive transillumination, while twenty-nine normal infants had a negative transillumination and only one of them had a borderline measurement. Pl. $b$ shows the intensity of the transillumination of one of the normal children; the rest of the children in this group were similar.

Analysis of liquid obtained by puncture. A bregmatic puncture was considered positive if it gave a rapid and continuous flow of colourless, transparent fluid, in a volume equal to or greater than $4 \mathrm{ml}$.

By this criterion, twenty-six of the thirty-two children with malnutrition gave positive results to the punctures; in a further three children between 2 and $3 \mathrm{ml}$ was obtained. It was easy to obtain $5 \mathrm{ml}$ or more from the majority of the children with malnutrition; it was not considered necessary to take more. Because of a diagnostic error for one child who was thought to have had a subdural effusion, $25 \mathrm{ml}$ were extracted. There was a close relationship between the intensity of the transillumination and the ease with which fluid was obtained by bregmatic puncture: those children whose transillumination included nearly the entire cranium gave fluid by puncture more easily and in greater quantity. In the four children with malnutrition whose transilluminations gave negative results, the punctures also gave negative results.

Table I. Comparative study of chemical composition of fuid obtained by bregmatic puncture $(B P)$ and of cerebro-spinal fluid (CSF) obtained by lumbar puncture in marasmic infants

\begin{tabular}{|c|c|c|c|c|c|c|}
\hline \multirow[b]{2}{*}{ Patient } & \multicolumn{3}{|c|}{ Protein $(\mathrm{mg} / \mathrm{1} 00 \mathrm{ml})$} & \multicolumn{3}{|c|}{ Glucose $(\mathrm{mg} / \mathrm{I} 00 \mathrm{ml})$} \\
\hline & BP & CSF & $\begin{array}{c}\text { Ratio, } \\
\text { BP:CSF }\end{array}$ & BP & CSF & $\begin{array}{c}\text { Ratio, } \\
\text { BP:CSH }\end{array}$ \\
\hline M.V. & 25.00 & $22 \cdot 00$ & $I \cdot 136$ & $62 \cdot 08$ & $60 \cdot 43$ & $1 \cdot 027$ \\
\hline J. G. & $28 \cdot 99$ & 24.97 & $I \cdot 160$ & $58 \cdot 78$ & $54 \cdot 20$ & $I \cdot 084$ \\
\hline D. S. & $27 \cdot 20$ & 25.49 & $1 \cdot 067$ & $38 \cdot 16$ & $39 \cdot 77$ & 0.960 \\
\hline M. R. & $50 \cdot 84$ & $48 \cdot 72$ & I.043 & $52 \cdot 24$ & $53 \cdot 12$ & 0.983 \\
\hline W.C. & $27 \cdot 20$ & $26 \cdot 78$ & 1.016 & $42 \cdot 08$ & $44 \cdot 00$ & 0.960 \\
\hline P.E. & $33 \cdot 45$ & 35.45 & 0.944 & $48 \cdot 08$ & $47^{\circ} 14$ & $1 \cdot 019$ \\
\hline E. O. & $45 \cdot 49$ & $44 \cdot 48$ & $1 \cdot 023$ & $58 \cdot 18$ & 55.22 & $1 \cdot 016$ \\
\hline L.M. & $22 \cdot 74$ & $22 \cdot 74$ & I 1000 & $62 \cdot 08$ & $60 \cdot 00$ & $I \cdot 035$ \\
\hline
\end{tabular}

The fluid obtained by bregmatic puncture from the marasmic children had a protein concentration of $20-60 \mathrm{mg} / 100 \mathrm{ml}$, a glucose concentration of $14-65 \mathrm{mg} / 100 \mathrm{ml}$ and no detectable bilirubin. These values correspond to those in cerebro-spinal fluid.

In the eight infants in whom the fluids obtained by bregmatic and lumbar puncture were compared, the glucose and protein concentrations were similar (Table I). This leads us to believe that the two liquids are identical. Immunoelectrophoretic separation of protein ( $\mathrm{Pl} .2 b)$ and the free amino acids pattern were also identical. 
To determine whether the liquid obtained by bregmatic puncture was the same as that in the lumbar subarachnoid space, radioactive iodinated albumin was injected into the latter area. By $2 \mathrm{~h}$ after the injection, radioactivity in the lumbar subarachnoid region was 3.6 times greater than in the bregmatic region, while that in the blood was 62 times less (Table 2). At I9 $\mathrm{h}$, amounts in both the bregmatic and cerebro-spinal fluid were considerably above that in the blood. These results limit the possibility of the passage of the albumin ${ }^{131} \mathrm{I}$ from the lumbar subarachnoid space to the bregmatic space by way of the blood, and suggest a free communication between the lumbar and bregmatic spaces.

Table 2. Distribution (counts/min per $m l$ ) of ${ }^{131} I$ in albumin in a marasmic infant 2 and $19 h$ after an injection of ${ }^{131} I$-labelled human albumin

$\begin{array}{cccr} & \text { Cerebro-spinal } & \text { Bregmatic } & \\ \text { Time } & \text { fluid } & \text { fluid } & \text { Blood } \\ 2 \mathrm{~h} & 53789 & 14944 & 239 \\ 19 \mathrm{~h} & 3764 & 5896 & 2496\end{array}$

\section{DISCUSSION}

With the technique of cranial transillumination, a clear difference was observed in the intensity of transillumination between a group of normal infants from 3 to I2 months old and a group of infants of the same age range with severe marasmic malnutrition. The bregmatic punctures gave ample quantities of fluid in almost all the children with malnutrition, while almost none was obtained by this means from the normal children. In addition, the intensity of transillumination of the malnourished children was proportional to the volume and ease with which fluid was obtained from the lumbar region. The results suggest that the transillumination phenomenon is due to the abnormal accumulation of fluid in the interior of the cranium. We cannot ignore the fact that a decreased bone density in malnourished children (Garn, I966) might influence these results; however, it seems unlikely to be the whole story, since the positive transillumination was correlated with positive puncture.

It has been observed that a subdural effusion will also give a positive transillumination (Rabe, Flynn \& Dodge, I962; Rabe, I967), which suggests the possibility that the marasmic children gave positive transillumination as a consequence of a subdural effusion. However, this hypothesis can be discarded because the fluids obtained by bregmatic and lumbar puncture were of the same composition and did not contain bilirubin (Rabe et al. 1962). And finally, the injection of the tracer ${ }^{131} \mathrm{I}$ indicated an ample communication between these fluids, thus excluding the possibility of subdural effusion (Rabe, Young \& Dodge, 1964).

These results lead us to assume that there exists an increase in cerebro-spinal fluid in the interior of the cranium of the children with severe marasmus. This could be due to an obstruction (hydrocephaly) or to an increase in production secondary to a reduced brain volume. If due to hydrocephaly there would be an elevated pressure of cerebro-spinal fluid and an eventual increase in cranial diameter. Pressure of the fluid was not recorded in this study, but it should be noted that in all the marasmic children 

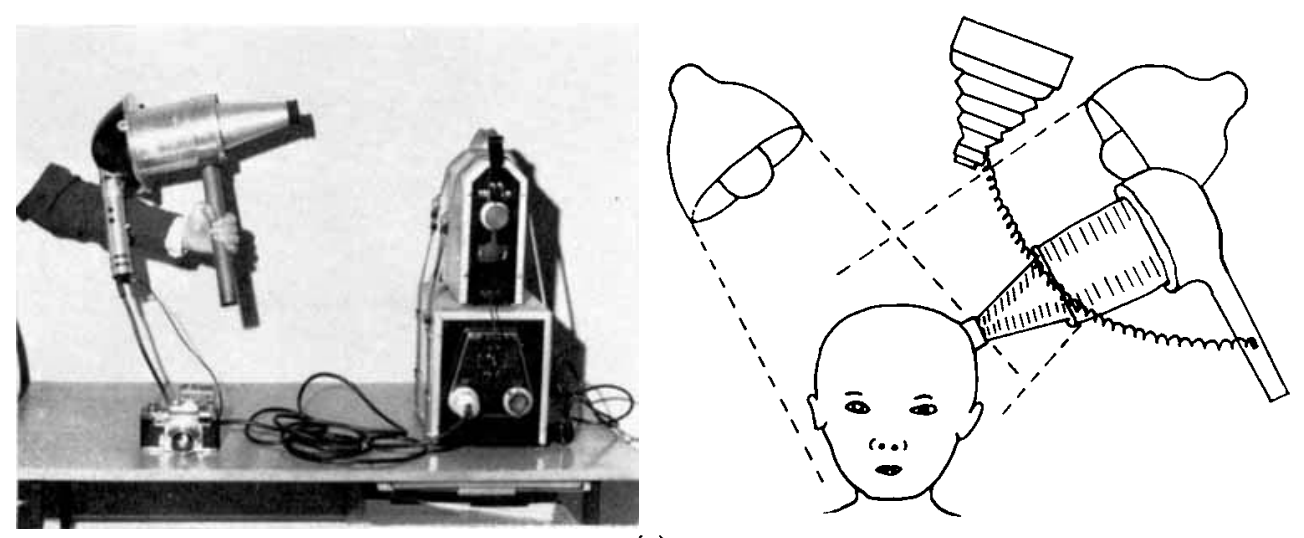

(a)

A
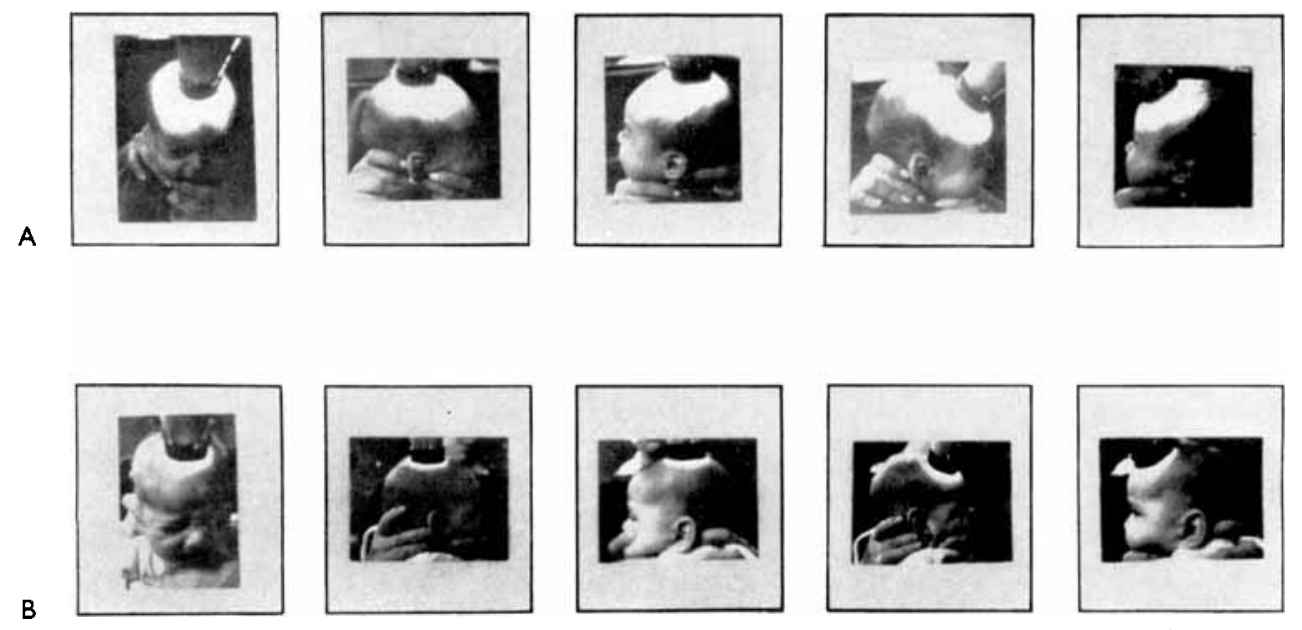

Bregmatic

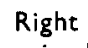

parietal

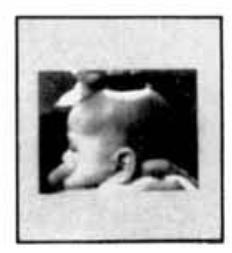

Left parietal

(b)

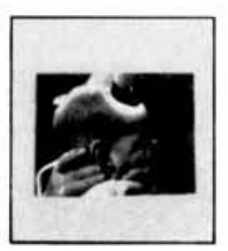

Right frontal

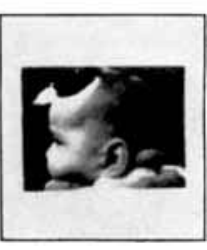

Left frontal 


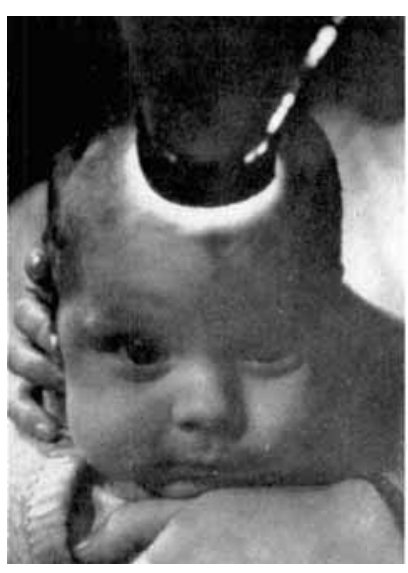

A

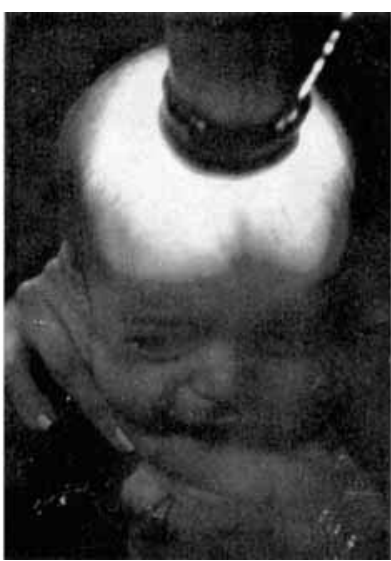

B

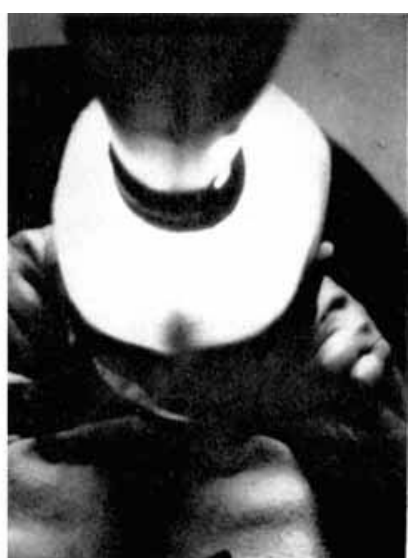

C

(a)

(b)

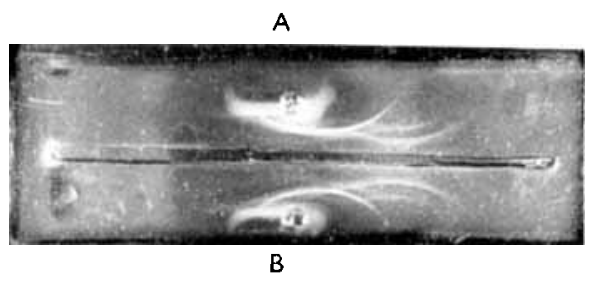


cranial diameter was more than two standard deviations below the normal for their ages. This decrease in cranial diameter has been observed even in malnutrition less intense than that described here (Mönckeberg et al. 1967).

These facts seem to demonstrate that malnutrition during the first months of life is associated with a brain size smaller than cranial capacity, which would result in a secondary increase in cerebro-spinal fluid. This reduction in brain size is even more intense if we consider the smaller cranial diameter of the marasmic child.

We believe that the transillumination method, because of its ease and lack of distress for the child, can be used as a convenient technique for studying the intensities of cerebral lesions and correlating these with clinical findings during the period of malnutrition and the following period of recuperation, which we are now studying.

This work has been supported by National Institute of Health, Research Grant $9 \mathrm{R} 22$ HD-0374r-o8, University of Chile and Nutrition Foundation. We thank Miss Sybille Lein for her excellent technical assistance.

\section{REFERENCES}

Dobbing, J. (1964). Proc. R. Soc. B I59, 503.

Dobbing, J. \& Widdowson, E. M. (1965). Brain 88, 357.

Garn, S. M. (1966). Publs natn. Res. Coun., Wash. no. 1282, p. 43.

Jackson, C. M. \& Steward, C. A. (1920). F. exp. Zool. 30, 97.

Lowry, O. H., Rosebrough, N. J., Farr, A. L. \& Randall, R. J. (1951). F. biol. Chem. 193, 265.

Malloy, H. T. \& Evelyn, K. A. (1937). F. biol. Chem. 119, 481 .

Mönckeberg, F. (1967). Malnutrition Learning and Behaviour p. 269 [N. S. Scrimshaw and J. E. Gordon, editors]. Boston: M.I.T. Press.

Mönckeberg, F., Donoso, G., Valiente, S. \& Arteaga, A. (1967). Rvta chil. Pediat. 38, 522.

Naeye, R. L. (1965). Archs Path. 79, 284.

Rabe, E. F. (1967). Pediat. Clins N. Am. 14, 831 .

Rabe, E. F., Flynn, R. E. \& Dodge, P. R. (1962). Neurology, Minneap. 12, 79.

Rabe, E. F., Young, G. F. \& Dodge, P. R. (1964). Neurology, Minneap. 14, 1020.

Scrimshaw, N. S. (1967). Am. F. clin. Nutr. 20, 493.

Smith, I. (editor) (1958). Chromatographic Techniques. London: Heinemann.

Somogyi, M. (1945). F. biol. Chem. 160, 69.

Stoch, B. \& Smythe, P. M. (1967). S. Afr. med. F. 4r, ro27.

Widdowson, E. M. (1966). Pan American Health Organization, W.H.O., Proc. Special Session During the Fourth Meeting of the PAHO Advisory Committee on Medical Research. Scientific Publ. I34, 27.

Widdowson, E. M., Dickerson, J. W. \& McCance, R. A. (1960). Br. F. Nutr. 14, 457.

Winick, M. \& Noble, A. (1966). F. Nutr. 89, 300.

\section{EXPLANATION OF PLATES}

\section{Plate I}

(a) Apparatus (left) for cranial transillumination and (right) the position of the child's head for transillumination.

(b) Cranial transillumination in five different positions of (A) a marasmic infant and (B) a normal infant.

\section{Plate 2}

(a) Cranial transillumination of (A) a normal infant and (B and C) infants with marasmic kwashiorkor.

(b) Immunoelectrophoretic separation of protein in (A) cerebro-spinal fluid and (B) fluid obtained by bregmatic puncture in infants with marasmic kwashiorkor. Central well: anti-human serum.

\section{Printed in Great Britain}

